DOI: $10.34185 / 1991-7848.2021 .01 .09$

УДК 669.184

Л.С. Молчанов, Т.С. Голуб, Є.В. Синегін, С.І. Семикін ${ }^{9}$

\title{
ДОСЛІДЖЕННЯ НА ФІЗИЧНІЙ МОДЕЛІ ОСОБЛИВОСТЕЙ ВПЛИВУ ЗАПИЛЕНОСТІ СЕРЕДОВИЩА НА ЯКІСНІ ПОКАЗНИКИ ГАЗОВОГО, ПАЛАЮЧОГО ФАКЕЛУ
}

\begin{abstract}
Процес кисневого конвертування супроводжується виділенням значного обсягу газів, що містять в основному продукти реакцій окислення вуглецю, які формують палаючий факел над горловиною конвертера. При цьому з конвертера виділяється значна кількість пилу різного складу і фракції в залежності від технологічних особливостей продувки, дослідження і облік впливу якої необхідний для розуміння якісних характеристик факела і конвертерного процесу вцілому. У роботі наведені результати дослідження на фізичної моделі, що імітує палаючий факел в запиленому середовищі, шляхом введення твердих порошків різних речовин, на якісні показники горіння факела: візуальні $i$ теплопередачу. Досліджено подачу в палаючий факел порошків хлориду натрію, оксидів заліза, кремнію та алюмінію, чистих порошків заліза, кремнію та алюмінію, сажі $i$ графіту. Встановлено, що введення різних компонентів в факел з температурою нижче, ніж температура факела, навіть при можливому візуальному збільшенні яскравості характеристик, що зокрема встановлено при введенні хлориду натрію або порошку заліза, сприяють зниженню теплопередачі від факела за рахунок відбору тепла на нагрівання і згоряння частинок, що вводяться.

Ключові слова: фізичне моделювання факелу допалювання конвертерних газів, порошкові матеріали, візуальні характеристики факелу, теплопередача.
\end{abstract}

\section{Вступ}

Киснево-конвертерний процес заснований на тісній взаємодії рідкої і газової фаз [1, 2]: основним чинником, що обумовлює протікання всіх процесів, служить спрямований потік кисню, а сам процес конвертування супроводжується виділенням значного обсягу газів, що містять продукти реакцій окислення вуглецю $\left(\mathrm{CO}\right.$ i $\left.\mathrm{CO}_{2}\right)$, а також азот, водень i кисень. Зазначені процеси при температурних i хімічних умовах конвертування супроводжуються горінням з утворенням факела: в порожнині конвертера в реакційній зоні i допалювання газів, що відходять, над горловиною конвертера [1, 2].

Кисневий факел, що забезпечує фізико-хімічні процеси в реакційній зоні, і факел допалювання газів, що відходять, тісно взаємопов'язані між собою [3]. Отже, вивчення і контроль останнього, як легше реєстрованого за ходом

(c) Молчанов Л.С., Голуб Т.С., Синегін Є.В., Семикін С.І., 2021 
продувки в умовах реальних високотемпературних процесів, може дати якісну інформацію про теплові і масообмінні процеси, що протікають в порожнині конвертера.

Значний газовий потік виносить 3 собою 3 конвертера також велику кількість пилу [4-6]. При верхній кисневій продувці пилевинос можна охарактеризувати наступними показниками [6]: концентрація загального заліза в пилу (57-79\%), металевого заліза (1,8-62\%), вміст вуглецю (0,7-2,6\%), діапазон розмірів частинок пилу складає 0,1-1000 мкм. Різнорідні частинки пилу, коли вони присутні в значній кількості, повинні впливати на властивості газового факелу, а значить актуальним $є$ дослідження впливу запиленості середовища на його характеристики.

3 огляду на вище наведене, в роботі було проведено дослідження на фізичній моделі впливу введення твердої порошкової фази на характеристики факела.

\section{Методика проведення досліджень}

Для проведення досліджень була виготовлена фізична модель, що дозволяє імітувати процес горіння газів, що відходять, в умовах запиленого середовища. Експериментальна установка представлена на фото на рисунку 1. Основним конструктивним елементом установки був газовий пальник, що формує палаючий факел. Сопло пальника і безпосередньо формуємий факел розміщувалися як в кварцовій трубі, що виключало вплив конвективних потоків при теплопередачі між факелом і мідною пластиною, яка реєструвала тепловий потік, для можливості виміру впливу вдуваємих порошків на теплопередачу від факелу випромінюванням, так і без неї для реєстрації загального теплового потоку. Порошок (3 кімнатною температурою) для створення газопорошкової суміші надходив 3 бункера безпосередньо в палаючий факел за допомогою вдування повітрям, що подавалося від компресора. В ході дослідів безперервно вимірювали температуру повітря в кімнаті в районі колби, температуру мідної пластини і температуру зовнішньої поверхні колби під факелом. Витрата порошку була постійною і визначалася зі зміни його маси.

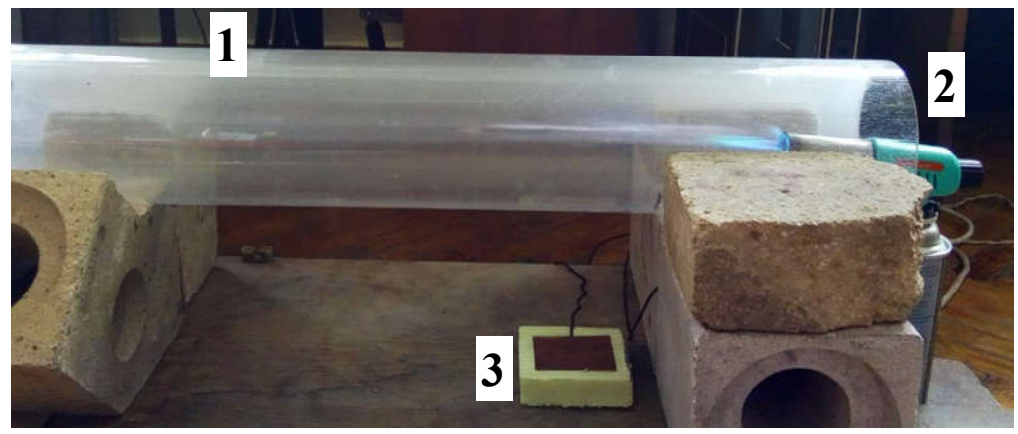

Рисунок 1 - Фото експериментальної установки: 1 - кварцова колба; 2 - газовий пальник; 3 - мідна пластина 
Оскільки в ході кожного досліду кварцова труба неминуче нагрівалася i сама ставала джерелом теплопередачі до мідної пластини, перед кожним дослідом її охолоджували до кімнатної температури потоком прохолодного повітря.

Для імітації запиленості факела використовували порошки $\mathrm{FeO}, \mathrm{Al}_{2} \mathrm{O}_{3}$, $\mathrm{NaCl}$, графіт, пісок, сажу, порошки заліза, алюмінію і кремнію. Діапазон розмірів частинок використовуваних порошків 50-460 мкм.

\section{Результати досліджень}

На рисунку 2 для прикладу наведені найбільш яскраво ілюструючі фото експериментів: 3 продувкою без порошку, з вдуванням в факел сажі, порошку заліза і хлориду натрію.
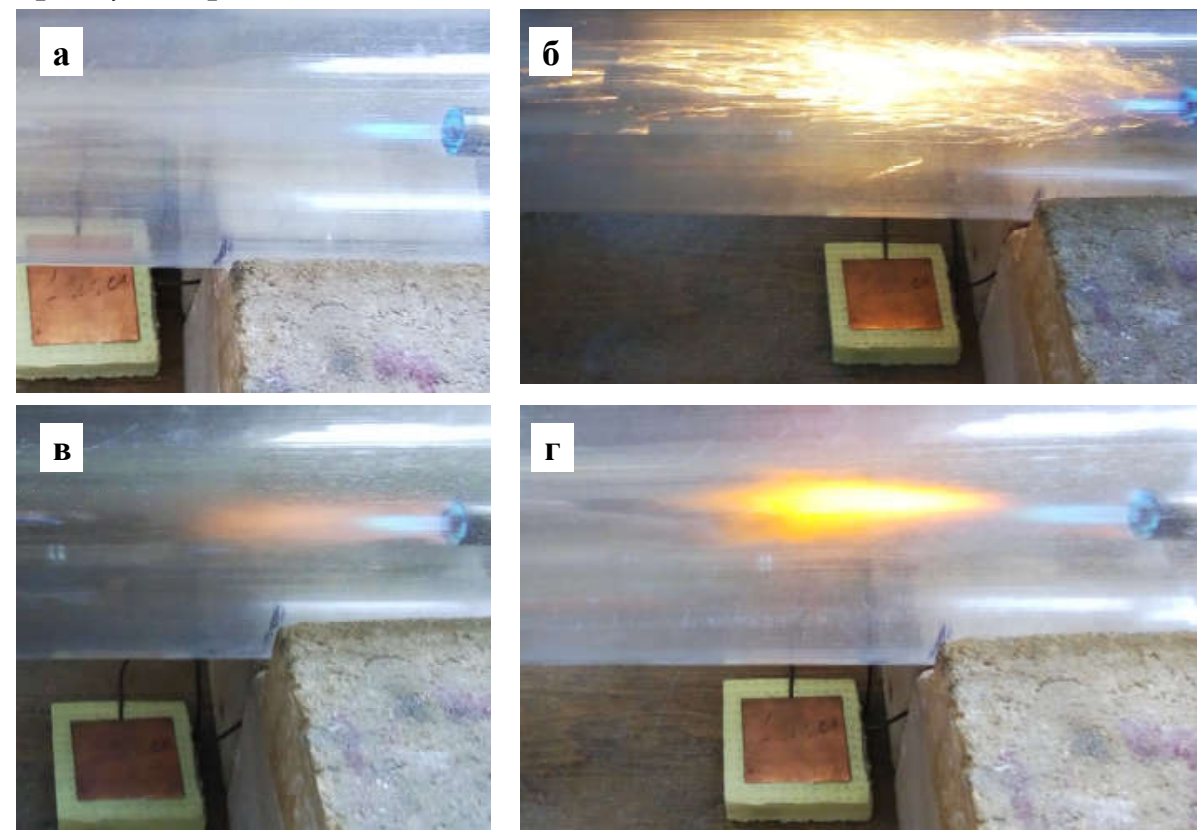

Рисунок 2 - Фото ділянок утворення факела для продувок: а - без порошку, б - подача порошку заліза, в - сажі, г - хлориду натрію

Було відзначено, що введення різних твердих, дрібнодисперсних компонентів в палаючий факел порізному відбивається на його видимих характеристиках. Так, при вдуванні в факел сажі і графіту відзначалося деяке візуальне збільшення його яскравості. Більш значуще збільшення візуальної яскравості відзначено при подачі порошку хлориду натрію 3 характерним жовтим світінням, а найбільше збільшення яскравості факела відповідало варіантові з подачею залізного порошку з утворенням великої кількості іскор палаючих частинок порошку (рисунок 2).

Крім збільшення візуальних показників яскравості відзначено зміну довжини видимого факела. Під час продування без подачі порошку в даних дослідах довжина видимої частини факела становила близько $57 \cdot 10^{-3} \mathrm{M}$, 
при подачі графіту або сажі довжина видимого факелу збільшувалася приблизно вдвічі. Введення порошку хлориду натрію призводило до збільшення довжини факелу у 4,7 рази, а при введенні порошку заліза відзначено найбільше збільшення довжини, з урахуванням іскор, приблизно в 6,7 разів (рисунок 3). Збільшення довжини видимої частини факелу свідчить про можливість деяких порошків випромінювати при нагріванні та згорянні при досягненні температури факелу (що в умовах даного експерименту складала близько $\left.1000{ }^{\circ} \mathrm{C}\right)$.

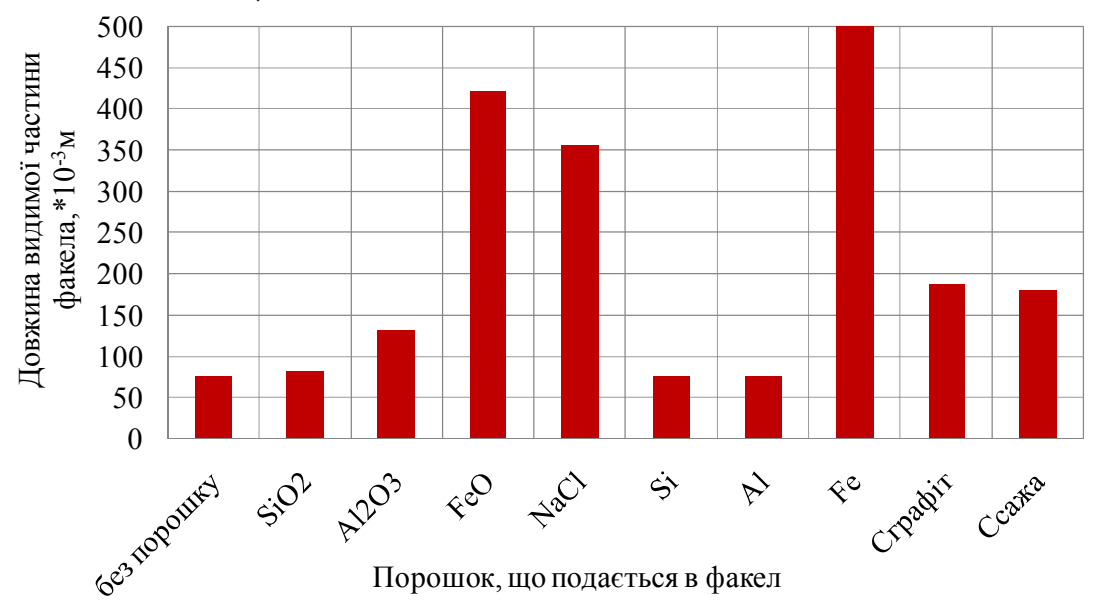

Рисунок 3 - Зіставлення довжини видимої частини факела при подачі в нього різних порошкових речовин

Порівняння ефективності теплопередачі випромінюванням, як основним шляхом передачі тепла від факела, при вдуванні в нього різних порошків було розраховано, виходячи 3 зареєстрованих даних, по величині середнього теплового потоку до мідної пластини за формулою [7]:

$$
q=\frac{{ }^{c_{C u}} m_{C u}\left(t_{\text {кін }}^{C u}-t_{\text {nоч }}^{C u}\right)}{f_{C u} \tau} \pm 3,26 \cdot\left|\bar{t}_{C u}-\bar{t}_{\text {оточ }}\right|^{5 / 4}, \mathrm{BT} / \mathrm{M}^{2},
$$

де $c_{C u}$ - питома теплоємкість мідної пластини, Дж/(кг $\left.{ }^{\circ} \mathrm{C}\right) ; m_{C u}-$ маса мідної пластини, кг; $t_{n о ч}^{C u}$ и $t_{\kappa i н}^{C u}-$ відповідно початкова і кінцева температура мідної пластини, ${ }^{\circ} \mathrm{C} ; f_{C и}-$ площа поверхні пластини, $\mathrm{M}^{2} ; \tau$ - час одного досліду, с; $\bar{t}_{C u}$ и $\bar{t}_{\text {оточ }}$ - відповідно середня температура мідної пластини і навколишнього середовища протягом досліду. На рисунку 4 наведено результати розрахунку. Як видно найбільша величина надлишкової щільності теплового потоку випромінюванням відповідає варіанту без подачі порошків. Введення порошкових матеріалів проявлося в зниженні величини теплового потоку випромінюванням, що пов'язано як з відбором тепла частинками порошку на нагрівання та згоряння, так і з тим, що введення порошків здійснювалося за допомогою перенесення потоком холодного повітря, що знижує температуру 
факела. При обліку того, що витрата повітря в усіх дослідах підтримувалася на однаковому рівні, за отриманими результатами можна якісно судити про вплив тієї чи іншої дослідженої речовини на теплопередачу випромінюванням. Так найменший вплив щодо всіх досліджених речовин чинила подача хлориду натрію (зниження величини теплового потоку випромінюванням в 1,42 рази). Далі по меншій величині впливу слідували порошки алюмінію, заліза, пісок і вуглець вмістні матеріали (сажа та графіт) (зниження величини теплового потоку в 1,70, 1,83, 1,93, 2,13 і 2,43 рази відповідно). Найбільший вплив серед досліджених речовин чинив порошок оксидів заліза і алюмінію (зниження щільності теплового потоку в 3,12 і 5,01 разів відповідно).

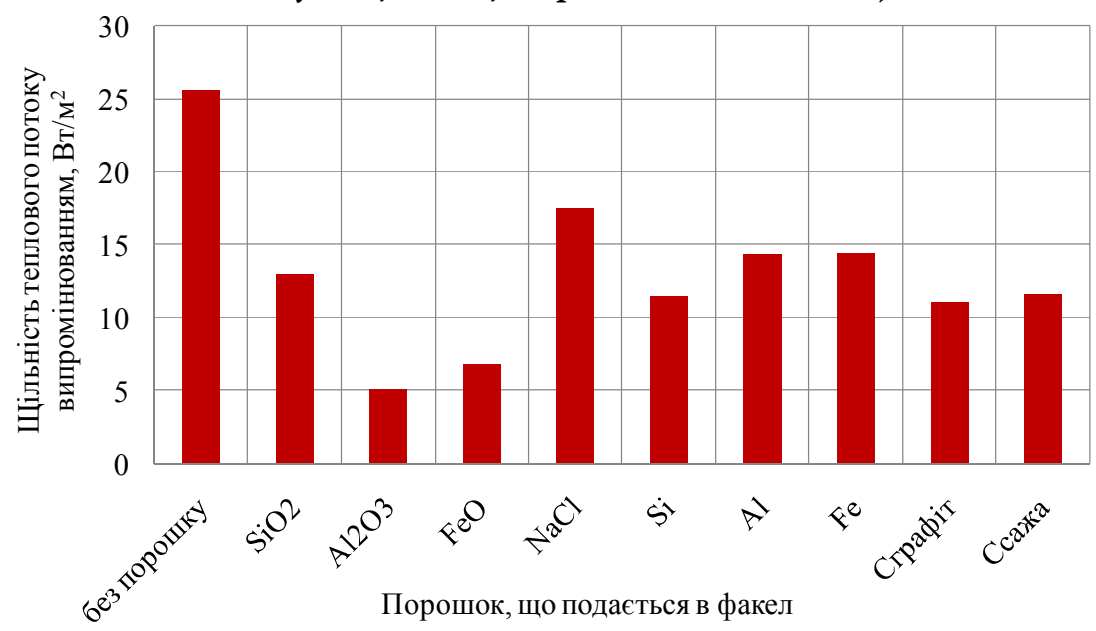

Рисунок 4 - Порівняння щільності теплового потоку випромінюванням при вдуванні різних порошків

Для кожного з варіантів подачі твердих матеріалів у палаючий факел був визначений також загальний тепловий потік i вклад різних типів теплопередачі: конвекцією, випромінюванням або контактним теплообміном у загальному обсязі теплового потоку (рисунок 5).

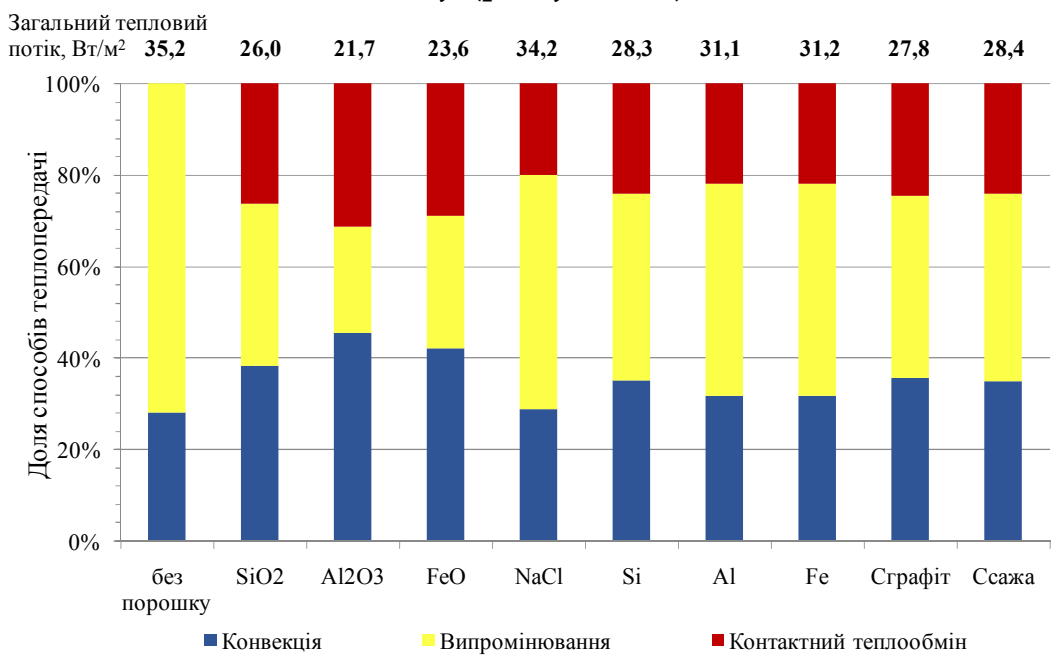

Рисунок 5 - Співвідношення різних типів теплопередачі при вдуванні різних порошків 
Аналіз отриманих даних свідчить про наступне. Не зважаючи на той факт, що вдування твердих «холодних» відносно температури палаючого факелу порошків значно (у рази) знижують показник випромінювання факелу, вплив на загальний тепловий потік твердих часток дещо інший. Це обумовлено додатковою можливістю перенесення тепла конвективними потоками та контактним теплообміном часток, що прогріваються палаючим факелом, 3 мідною пластиною (у разі продування без кварцової труби). Встановлено, що серед переліку випробуваних порошків найменший вплив чинить вдування порошку $\mathrm{NaCl}$ (зниження загального теплового потоку на 2,8\%), а найбільший вплив чинить вдування порошків оксидів заліза і алюмінію (зниження загального теплового потоку на 33,0 та 38,3\%).

\section{Висновки}

Таким чином, проведені дослідження на фізичній моделі дозволили якісно дослідити вплив введення різних порошкових матеріалів на такі характеристики палаючого факелу, як візуальні показники і теплопередачу від факелу. Виявлено, що подача будь-якого твердого матеріалу з температурою значно нижчою за температуру факела найбільш негативно відбивається на теплопередачі від факела випромінюванням навіть при можливому візуальному збільшенні яскравості показників. Проте на загальний тепловий потік подача твердих матеріалів у палаючий факел чинить значно менший вплив. Отже, для розуміння реально протікаючих в конвертері процесів допалювання газів, що відходять (наприклад, при оцінці теплопередачі факела ванні), необхідно враховувати поточні умови горіння факела, які залежать від технологічних особливостей ведення плавки.

\section{ЛIТЕРАТУРА}

1. Бигеев А. М. Металлургия стали. Теория и технология плавки стали / А. М. Бигеев. Челябинск: - Металлургия, 1988.- 479 с.

2. Баптизманский В. И. Теория кислородно-конвертерного процесса / В. И. Баптизманский М.: Металлургия, 1975. - 376 с.

3. АСУТП в конвертерном производстве: Учебник / А.Г.Величко, В.П.Иващенко, А.А.Верховская, В.И.Головко, А.Н.Селегей. - Днепропетровск: НМетАУ, 2016. - 245 с.

4. Симонян Л. М. Особенности пылеобразования при кислородной продувке расплава и возможные пути использования уловленной пыли / Л. М. Симонян, Н. М. Говорова // Металлург. - 2011. - № 6. - С. 78-85.

5. Кожухов А. А. Моделирование газоструйной пылеочистки над зоной продувки кислородного конвертера / А. А. Кожухов, Э. Э. Меркер, А. А. Шевченко // Металлург .- 2010. - № 9. С. 41-44.

6. Охотский В. Б. Характеристика пылеуноса при продувке металла окислительным газом / В. Б. Охотский // Металлургическая и горнорудная промышленность. - 2000. - № 5. - С. 100-102.

7. Румянцев В.Д. Теория тепло - и массообмена/ В.Д. Румянцев.- Днепропетровск: Пороги, 2006. - 532 c. 


\section{REFERENCES}

1. Bigeev A. M. (1988) Metalurgiia stali. Teoriya i tehnologiia plavki stali, Cheliabinsk: Metallurgiia, 479 p. [in Russian]

2. Baptizmanskiy V. I. (1975) Teoriia kislorodno-konverternogo processa, Moscow: Metallurgiia, 376 p. [in Russian]

3. Velichko A.G., Ivashenko V.P., Verhovskaia A.A., Golovko V.I., Selegey A.N.(2016) ASUTP v konverternom proizvodstve, Dnepropetrovsk: NmetAU, 245 p. [in Russian]

4. Simonian L. M., Govorova N.M. (2011) Osobennosti pileobrazovaniia pri kislorodnoy produvke rasplava i vozmozniie puti ispolzovaniia ulovlennoy pyli, Metallurg , no.6, P. 78-85. [in Russian]

5. Kozhuhov A. A., Merker E.E., Shevchenko A.A. (2010) Modelirovaniie gazostruynoy puleochistki nad zonoy produvki kislorodnogo konvertera, Metallurg, no. 9, P. 41-44. [in Russian]

6. Okhotskiy V.B.(2000) Haracteristiki pileunosa pri produvke metalla okislitelnym gazom, Metallurgicheskaia i gornorudnaia promyshlennost, no. 5, P. 100-102. [in Russian]

7. Rumiantsev V.D. (2006) Teoriia teplo- $i$ massoobmena, Dnepropetrovsk: Porogi, 532 p. [in Russian]

Received 12.01.2021.

Accepted 21.01.2021.

UDC 669.184

L. Molchanov, Ye. Sinegin, T. Golub, S. Semykin

\section{INVESTIGATIONS ON THE PHYSICAL MODEL OF THE PECULIARITIES OF THE INFLUENCE OF DUST ON THE QUALITY INDICATORS OF A GAS BURNING TORCH}

The oxygen converter process is accompanied by the release of a significant amount of gases, containing mainly the products of carbon oxidation reactions, which form a burning torch over the neck of the converter. A significant amount of dust of different composition and fraction is also released from the converter depending on the technological features of the blowing, the study and accounting of the impact of which is necessary to understand the qualitative characteristics of the torch and the converter process in general. The paper presents the results of a study on a physical model simulating a burning torch in a dusty environment, by introducing solid powders of various substances, on the qualitative indicators of torch combustion: visual and heat transfer. The supply of powders of sodium chloride, oxides of iron, silicon and aluminum, pure powders of iron, silicon and aluminum, carbon black and graphite to the burning torch was investigated. It was established that the introduction of various components into the torch with a temperature lower than the temperature of the torch, even with a possible visual increase in brightness characteristics, in particular when introducing sodium chloride or iron powder, reduce heat transfer from the torch due to the heat absorption for heating and combustion of introduced particles.

Keywords: physical modeling of postcombustion converter gas torch, powder materials, visual characteristics of torch, heat transfer. 
Молчанов Лавр Сергійович - к.т.н, завідуючий відділом Фізико-технічних проблем металургії сталі, Інститут чорної металургії ім. 3.І. Некрасова НАН України.

Синегін Євген Володимирович - к.т.н., доцент кафедри Металургії чавуну і сталі, Національна металургійна академія України.

Голуб Тетяна Сергіївна - к.т.н., старший науковий співробітник відділу Фізикотехнічних проблем металургії сталі, Інститут чорної металургії ім. 3.І. Некрасова НАН України.

Семикін Сергій Іванович - к.т.н., с.н.с., старший науковий співробітник відділу Фізико-технічних проблем металургії сталі, Інститут чорної металургії ім. 3.І. Некрасова НАН України.

Molchanov Lavr - Ph.D., Head of the Department of Physical and Technical Problems of Steel Metallurgy, Z. I. Nekrasov Iron \& Steel Institute of NAS of Ukraine.

Synegin Yevhen -Ph.D., Associate Professor of the Department of Iron and Steel Metallurgy, The National Metallurgical Academy of Ukraine.

Golub Tetiana -Ph.D., senior researcher of the Department of Physical and Technical Problems of Steel Metallurgy, Z. I. Nekrasov Iron \& Steel Institute of NAS of Ukraine.

Semikin Sergiy - Ph.D., senior researcher, senior researcher of the Department of Physical and Technical Problems, Z. I. Nekrasov Iron \& Steel Institute of NAS of Ukraine. 